6. Petrychenko V.F., Lykhochvor V.V. (2014). Roslynnytstvo. Tekhnolohii vyroshchuvannia silskohospodarskykh kultur [Plant growing. Technology of growing crops]. Lviv, 1040 p. (in Ukrainian).

7. Volkohon V.V., Salnyk V.P. (2005). Znachennia rehuliatoriv rostu u formuvanni aktyonykh azotfiksuvalnykh symbioziv ta asotsiatsii [Value growth regulators in the formation of active azotfiksuvalnyh symbioses and associations]. [Physiology and biochemistry cultural plants]. Vol. 37, No. 3 . pp. 187-197 (in Ukrainian).
8. Tolstoukhov A.V., Khylko M.I. (2007). Ekobezpechnyi rozvytok: poshuk stratehem [Ecosafety development: strategies]. Kyiv: Znannia Ukrainy Publ., 332 p. (in Ukrainian).

9. Furdychko O.I. (2012). Dovidnyk z ahroekolohii ta pryrodokorystuvannia [Handbook of Agroecology and Environmental Sciences]. Kyiv, 177 p. (in Ukrainian).

10. Dospekhov B.A. (1985). Metodika polevogo opyta [Methods of field experience]. Moscow: Agropromizdat Publ., 351 p. (in Russian).

\title{
THE APPLICATION OF MINERAL FERTILIZERS IN ORDER TO RESTORE FOREST ECOSYSTEMS CONTAMINATED WITH RADIONUCLIDE ${ }^{137} \mathrm{Cs}$
}

\author{
M. Vinichuk ${ }^{1}$, Y. Mandro' ${ }^{1}$ K. Rosén ${ }^{2}$ \\ ${ }^{1}$ Житомирський держсвний технологічний університет \\ ${ }^{2}$ Шведський університет сільськогосподарських наук
}

\begin{abstract}
Узагальнено результати трирічних досліджень щодо ефективності впливу разового внесення деревної золи як забрудненої, так і не забрудненої ${ }^{137} \mathrm{Cs}$, а також за їх поєднаного внесення з калійними добривами на зменшення переходу радіонукліда з грунту у молоді пагони та листя деяких видів дерев та дикорослих ягідних рослин лісових екосистем Полісся України. Продемонстровано, що разове внесення як забрудненої ${ }^{137} \mathrm{Cs}$ деревної золи, так і не забрудненої у поєднанні з калійними добривами (50:50 у відсотковому складі за калієм) з розрахунку 100 кг у д.р. калію на 1 га знижує перехід радіонукліда з грунту у досліджувані рослини, в середньому за три роки на 35 та $20 \%$ відповідно. Для деяких видів дикорослих ягідних рослин (молоді пагони та листя чорниці і брусниці), а також деревних порід (молоді пагони та листя горобини і дуба) коефіцієнти переходу ${ }^{137}$ Cs на третій (2014) рік після внесення меліорантів знизились на 40-70\% порівняно з рослинами контрольного варіанта.
\end{abstract}

Ключові слова: деревна зола, калійні добрива, лісові рослини, грунт.

The use of bio-energy derived from biofuels has increased in recent years, which means that the amount of ash, which has to be taken care of is also increasing. Among other elements ash contains available potassium $(\mathrm{K})$, which can be used as a fertilizer in contaminated forest and prevent accumulation of cesium. Most of those ashes have such properties that they meet the quality requirements of Forest Agency set up in their recommendations for returning the ashes to the forest. Ash

(C) M. Vinichuk, Y. Mandro, K. Rosén, 2016 could serve as a soil amendment in forest and also as a measure to reduce the uptake of ${ }^{137} \mathrm{Cs}$ in woodland plants, especially fungi. Ashes coming from energy crop biofuels i.e. agricultural energy crops, short-rotation woody crops grown on contaminated soils can be used on arable land with similar purposes.

Following the Chernobyl accident in 1986 large areas of Ukraine, including forest areas were contaminated by the fallout of radioactive cesium $\left({ }^{137} \mathrm{Cs}\right)$. Even today, nearly 30 years after the accident, the elevated levels of ${ }^{137} \mathrm{Cs}$ in soil and forest vegetation, espe- 
cially in fungi can be found in these areas. Besides mushrooms and berries, also animals (for example moose, wild boar) that reside in these areas have elevated ${ }^{137} \mathrm{Cs}$ values. The transfer of radiocesium to non-farm products (e.g. edible fungi, game animals) is often much greater than that to agriculturally produced foodstuffs [1]. This means that people who consume these non-farm products may increase their internal radiation dose [2].

Bioashes and especially wood ashes often have a relatively high content of potassium: $3-6 \%$ of the dry matter content compared with other ashes [3]. Peat ashes generally have lower nutrient levels (e.g., K) than wood ashes. Fly ashes usually have higher K content than bottom ashes. Supply of mineral fertilizers that are high in potassium (e.g., $\mathrm{KCl}$ ) to soil that has been contaminated with radioactive cesium, has been shown to reduce plant uptake of ${ }^{137} \mathrm{Cs}$ [4]. Ash recycling to forest and agricultural soils would thus also be used as a measure to reduce the uptake of ${ }^{137} \mathrm{Cs}$ in plants.

Biofuels from areas contaminated with radioactive cesium has also elevated ${ }^{137} \mathrm{Cs}$ values, which means that ash from the combustion of these biofuels also has high levels of ${ }^{137} \mathrm{Cs}$. Ashes were considered to be contaminated when the levels of ${ }^{137} \mathrm{Cs}$ exceed $0.5 \mathrm{kBq} / \mathrm{kg}$ dry matter. The ashes that have concentrations of ${ }^{137} \mathrm{Cs}$ over $10 \mathrm{kBq} / \mathrm{kg}$ per dry weight cannot be spread in woodland [5].

In earlier studies dealing with how the application of wood ash affects the content of radioactive cesium in forest plants they have usually studied the effect of ash contaminated with radioactive ${ }^{137} \mathrm{Cs}$ on ${ }^{137} \mathrm{Cs}$ uptake in a specific plant [6] or in plants in drained peatlands [7] or on the mineral soil [8]. These studies showed that, in general, the concentration of ${ }^{137} \mathrm{Cs}$ in berries, mushrooms and tree parts generally did not increase or even decreased when grown on soils where contaminated ash was added. It can be plausibly explained that both potassium and cesium ions have similar properties. Thus, plants will take up less cesium ions if there is an excess of potassium ions.

Previous studies have also shown that potassium fertilization (usually $\mathrm{KCl}$ ) can reduce the absorption of radioactive $\mathrm{Cs}$ in plants, and therefore, potentially reduce the levels of ${ }^{137} \mathrm{Cs}$ in the animals that eat these plants [6]. The effects of potassium fertilization in forest on the concentration of ${ }^{137} \mathrm{Cs}$ in plants can be observed both in the short and long term. Below is a brief summary of the results from these studies.

Strandberg and Johansson showed that the application of $\mathrm{K}\left(10 \mathrm{~kg} / \mathrm{ha}^{-1}\right)$ reduced the concentration of ${ }^{134} \mathrm{Cs}$ in shoots of heather in the short term ( 8 months) by approximately $49 \%$ [9]. Zibold et al., observed that 11 years after application of 2.5 tons of lime (containing about $5 \% \mathrm{~K}$ ) to a ${ }^{137} \mathrm{Cs}$ contaminated spruce forest in southern Germany the uptake of ${ }^{137} \mathrm{Cs}$ in plants such as ferns (Dryopteris carthusiana) and blackberries (Rubus fruticosus) grown on fertilized plots was 25 times lower compared to control plots [10]. Both short and long term effects of $\mathrm{K}$ fertilization in pine forest were observed by Aro and Rantavaara in western Finland. In the Finnish study the concentration of ${ }^{137} \mathrm{Cs}$ in pine needles decreased significantly or noticeably during 1-21 years after the application of potassium fertilizers [11].

In a recent article, we have presented the results of both the short and long term effects of a single dose application of potassium $\left(100 \mathrm{~kg} \mathrm{~K} \mathrm{ha}^{-1}\right)$. Such investigation on the ${ }^{137} \mathrm{Cs}$ uptake by green aboveground parts of heather, lingonberry, blueberry and four fungal species was conducted in 1992. The uptake of ${ }^{137} \mathrm{Cs}$ in the plants and fungi 17 years after treatment was the significantly lower in the areas where potassium was applied compared with the uptake in control plots. In fruit bodies of mushrooms the concentration of ${ }^{137} \mathrm{Cs}$ was from 21 to $58 \%$ lower on the K-fertilized plots compared to control plots where the plants showed between 40 and $61 \%$ reduction. The reduction of ${ }^{137} \mathrm{Cs}$ uptake in tested plants and fungi was greatest in the first years after the treatment, but still was pronounced even 17 years after the treatment [4].

The aim of this study was to provide evidence that wood ash (both, ${ }^{137} \mathrm{Cs}$-contaminated and uncontaminated) is a feasible solution to reduce plant uptake of radioactive 
cesium in woodland areas affected by high radioactive fallout. Our hypothesis was that wood ashes have relatively high potassium content and there will be an excess of plantavailable potassium ions when applied to the soil, which in turn will decrease plants uptake of cesium ions. Reducing effect of wood ashes on plant uptake of radioactive cesium where compared with effect of mineral fertilizers $(\mathrm{KCl})$ and with untreated surfaces.

Particular attention was focused on the forest plants that serve as food for such wild animals as moose [12], deer and wild boar [13]. It is expected that results from this study will show how wood ash, combination of ash and potassium fertilizer, as well as ash characteristics including level of ${ }^{137} \mathrm{Cs}$ in cesium-contaminated ash, affect the short and long-term uptake of ${ }^{137} \mathrm{Cs}$ by experimental plants.

\section{MATERIALS AND METHODS}

The experiment was started in 2012 and it is still ongoing. It is expected that the maximum effect of single ash/fertilizers application will be seen after experiment is being conducted for several years. The experimental area is located in Bazar forestry, Zhytomyr region, Ukraine, about $70 \mathrm{~km}$ from Chernobyl NPP $\left(51^{\circ} 5^{\prime} 35^{\prime \prime} \mathrm{N}, 29^{\circ} 18^{\prime} 56^{\prime \prime} \mathrm{E}\right) .{ }^{137} \mathrm{Cs}$ deposition in this area is between $177-355 \mathrm{kBq} / \mathrm{m}^{2}$. The major soil type in the study area is soddy podzolic. The thickness of the organic horizon did not exceed 3-5 cm. Main chemical characteristics of studied soil to the depth of $0-1$ $5 \mathrm{~cm}$ are as follows: $\mathrm{pH} 4.25 \pm 0.47$, Tot-C $2.96 \pm 1.93 \%$, Tot-N $0.12 \pm 0.09 \%$, C/N 24.76 \pm $\pm 2.78, \mathrm{~K}-\mathrm{AL} 7.03 \pm 6.36 \mathrm{mg} / 100 \mathrm{~g}, \mathrm{Ca}-\mathrm{AL}$ $16.82 \pm 19.22 \mathrm{mg} / 100 \mathrm{~g}, \mathrm{~K}-\mathrm{HCl} 15.63 \pm$ $\pm 6.31 \mathrm{mg} / 100 \mathrm{~g}, \mathrm{Ca}-\mathrm{HCl} 22.85 \pm 21.70 \mathrm{mg} / 100 \mathrm{~g}$ (mean $\pm \mathrm{SD}, \mathrm{n}=14$ ).

Experimental plots were randomly designed within an area about 0.6 ha and individual plot area of $200(20 \times 10) \mathrm{m}^{2}$ was chosen to obtain sufficient sample material. Spreading of ashes and potassium fertilizers was done by hand. Before treatment, the ashes were analyzed for the $\mathrm{pH}$ level, the content of ${ }^{137} \mathrm{Cs}, \mathrm{K}$, Ca and P. Depending on the potassium content in ashes, the ash applica- tion rate of $100 \mathrm{~kg} \mathrm{~K} \mathrm{ha}^{-1}$ was determined to ensure potassium supply with ashes. There were six treatments with four replicates: $1-$ control, 2 - KCl, 3 - ash, 4 - ash (contam.), $5-50 \%$ ash $+50 \% \mathrm{KCl}, 6-50 \%$ ash (contam.) $+50 \% \mathrm{KCl} .{ }^{137} \mathrm{Cs}$ activity concentration in contaminated ash (ash (contam.)) varied between $15700-18870 \mathrm{~Bq} / \mathrm{kg}$ d.w. (dry weight), while uncontaminated ash had 46,0 Bq/kg d.w. Potassium content in both ashes was $3.1-3.4 \%$.

The dominating trees were Scots pine (Pinus sylvestris) with some intermixed birch (Betula pendula). The stand was approximately $60-80$ years old. There were also rowan (Sorbus aucuparia), oak (Quercus), buckthorn (Rhamnus frangula). The most common shrubs were blueberry (Vaccinium myrtillus), cowberry (Vaccinium vitis-idaea), and heather (Calluna vulgaris). Soil ground and bark surface of trees were partly covered by mosses and lichens.

Sampling of soil was performed before and after treatment by using a cylindrical steel core with a diameter of $57 \mathrm{~mm}$ and a length of the working section of $150 \mathrm{~mm}$. For spectrometric measurements soil was airdried to constant weight, milled and sieved through $2 \mathrm{~mm}$ sieve to produce homogeneous material. Young aboveground green parts of blueberry and cowberry as well as young shoots and leaves of available trees (rowan, birch etc.) were taken 3 times per year (in May, July and September) during 20122014 for gamma spectrometric measurements.

Measurements of ${ }^{137} \mathrm{Cs}$ activity concentration $(\mathrm{Bq} / \mathrm{kg}$ dry weight) in samples of plants, berries and soil were performed by using HPGe detectors at Swedish University of Agricultural Sciences (Sweden) and by using NaI detector at Zhytomyr State Technological University (Ukraine). Results were decay-corrected to the date of sampling. Statistical treatment of data was performed using Windas and Minitab software package Minitab® 16.2.4. Aggregated transfer factor $\left(T_{a g}\right)-$ coefficient of radiocesium transfer from soil to plant material was calculated as described in IAEA [14]. 


\section{RESULTS AND DISCUSSION}

There was relatively little rainfall in the first and second decade of July 2012, in July and August 2013 and in the second half of June 2014. More than double amount of rainfall was recorded in the second decade of May and first decade of June during all three years. Air temperature varied over the years of study, however generally followed the many years trend.

Blueberry. Single fertilization with potassium $(\mathrm{KCl})$ fertilizers increased radionuclide transfer from soil to blueberry plants in first (2012) year after fertilizer application. Meanwhile, there was a clear decrease of ${ }^{137} \mathrm{Cs} \mathrm{TF}$ (transfer factor) from soil to blueberry plants in following (2013 and 2014) years resulting in about 2-fold decrease of TF in 2014 (table 1), when radionuclide transfer to experimental and control plants was similar. Following the tendency it can be expected that ${ }^{137} \mathrm{Cs} \mathrm{TF}$ to blueberry will decrease with time. Combination of potassium fertilizers with wood ash resulted in lower ${ }^{137} \mathrm{Cs} \mathrm{TF}$ to blueberry in all there growing seasons (2012-2014). The difference between ${ }^{137} \mathrm{Cs} \mathrm{TF}$ for control blueberry plants and plant growing on fertilized plots increases with time. This tendency become even more pronounced in treatment with contaminated wood ash; ${ }^{137} \mathrm{Cs} \mathrm{TF}$ in 2014 for plants fertilized with contaminated wood ash was about 30\% lower compared to control plants. Application of uncontaminated ash did not show noticeable effect on

Table 1

Effect of forest soil fertilization with potassium fertilizer $(\mathrm{KCl})$, contaminated wood ash (ash (contam.)), uncontaminated wood ash (ash) and their combination on ${ }^{137} \mathrm{Cs}$ TF from soil to forest plants and trees shoots in third (2014) and fourth (2015) years, \pm to control, \%. «+»- positive effect, «-»- negative effect

\begin{tabular}{|c|c|c|c|c|c|}
\hline Control & $\mathrm{KCl}$ & $\mathrm{ash}+\mathrm{KCl}$ & ash (contam.) & ash & ash $($ contam. $)+\mathrm{KCl}$ \\
\hline \multicolumn{6}{|c|}{ Blueberry (aboveground plant) } \\
\hline 2014 & -14.0 & 29.5 & 31.4 & 19.6 & 45.0 \\
\hline 2015 & 1.3 & 41.6 & 47.1 & 34.5 & 59.9 \\
\hline \multicolumn{6}{|c|}{ Cowberry (aboveground plant) } \\
\hline 2014 & 22.3 & 45.2 & 29.0 & 15.5 & 67.9 \\
\hline \multirow[t]{2}{*}{2015} & 14.3 & 33.7 & 40.6 & 1.7 & 59.1 \\
\hline & & \multicolumn{4}{|c|}{ Rowan (young shoots and leaves) } \\
\hline 2014 & 39.5 & 66.4 & 59.6 & 39.1 & 77.0 \\
\hline \multicolumn{6}{|l|}{$2015^{*}$} \\
\hline & & \multicolumn{4}{|c|}{ Birch (young shoots and leaves) } \\
\hline 2014 & 9.1 & 44.8 & 60.0 & 19.3 & 65.1 \\
\hline \multicolumn{6}{|l|}{$2015^{*}$} \\
\hline \multicolumn{6}{|c|}{ Buckthorn (young shoots and leaves) } \\
\hline 2014 & -21.9 & 9.8 & 16.4 & 1.5 & 39.0 \\
\hline \multicolumn{6}{|l|}{$2015^{*}$} \\
\hline \multicolumn{6}{|c|}{ Oak (young shoots and leaves) } \\
\hline 2014 & 31.5 & -11.0 & 41.2 & -11.4 & 66.9 \\
\hline $2015^{*}$ & & & & & \\
\hline
\end{tabular}

*Data for 2015 are in progress. 
${ }^{137} \mathrm{Cs}$ TF to blueberry plants, while effect was more pronounced when uncontaminated ash was applied in combination with potassium fertilizer. Reduction of ${ }^{137} \mathrm{Cs}$ TF in 2014 was about $45 \%$. Data on ${ }^{137} \mathrm{Cs} \mathrm{TF}$ to blueberry plants in 2015 are evidencing further decrease of radionuclide transfer from forest soil to plants. Thus, in treatment $\mathrm{KCl}+$ ash (contam.) ${ }^{137} \mathrm{Cs}$ TF to blueberry plants was found to be about $60 \%$ lower compared to control.

Cowberry. Fertilization with potassium increased ${ }^{137} \mathrm{Cs} \mathrm{TF}$ to cowberry plants in the first (2012) year, however, it reduced radionuclide transfer from forest soil to plants already in the second (2013) and the third (2014) year (table 1). Application of potassium fertilizer in combination with ash appeared to be more effective; ${ }^{137} \mathrm{Cs} \mathrm{TF}$ to cowberry plants reduced already in the first year, when maximum effect was seen in the second year after single fertilization. Application of ash contaminated with ${ }^{137} \mathrm{Cs}$ caused similar effect: ${ }^{137} \mathrm{Cs}$ TF to cowberry plants was reduced by about 50\%. Uncontaminated ash showed more or less the same effect, most pronounced effect was seen in the second (2013) year after fertilization. Joint application of potassium and contaminated with ${ }^{137} \mathrm{Cs}$ ash had also effect on radionuclide transfer from forest soil to cowberry aboveground green shoots. Reduction of ${ }^{137} \mathrm{Cs}$ TF to cowberry plants was most pronounced in the second year (2013) after fertilization. ${ }^{137} \mathrm{Cs} \mathrm{TF}$ to cowberry plants further increased in 2015 but was still lower then on control.

Rowan. Single fertilization of forest soil with potassium fertilizer and both contaminated and uncontaminated wood ashes appeared to be effective countermeasure reducing ${ }^{137} \mathrm{Cs}$ TF from soil to rowan shoots. Combined application of potassium fertilizer with contaminated and uncontaminated ashes reduced radionuclide transfer to shoots already in the first year. The effect for $\mathrm{KCl}$ and contaminated ash was not seen in the first year, however, both fertilizers showed obvious reduction of cesium transfer from soil to rowan shoots in the following (2013, 2014 ) years. Fertilization effect was most pronounced in the third year (2014) for treat- ments with contaminated ash, contaminated ash $+\mathrm{KCl}$ as well as for uncontaminated ash $+\mathrm{KCl} .{ }^{137} \mathrm{Cs} \mathrm{TF}$ from soil to rowan shoots on those treatments in 2014 reduced by about $60 \%$ compared to control plots (table 1 ).

Birch. ${ }^{137} \mathrm{Cs}$ transfer from forest soil to birch shoots generally decreased in the years after single fertilization of soil with potassium fertilizer and both contaminated and uncontaminated wood ashes. The most pronounced difference in radiocesium uptake by birch shoots between those growing on the control and on the experimental plots was found in the third (2014) year. Thus, combined application of $\mathrm{KCl}+$ uncontaminated ash, contaminated ash as well as $\mathrm{KCl}+$ contaminated ash caused $45-60 \%$ reduction of ${ }^{137} \mathrm{Cs}$ TF from soil to birch shoots (table 1). Separate fertilization with $\mathrm{KCl}$ and uncontaminated ash did not reduce ${ }^{137} \mathrm{Cs} \mathrm{TF}$ from soil to birch shoots in the third (2014) year after treatment.

Buckthorn. Single application of potassium fertilizer as well as wood ashes generally did not decrease ${ }^{137} \mathrm{Cs} \mathrm{TF}$ from forest soil to buckthorn shoots compared to control plants under first three years after fertilization. There was, however, a clear trend indicating progressive reducing of ${ }^{137} \mathrm{Cs} \mathrm{TF}$ from year to year, suggesting that reducing effect of soil fertilization might be seen in the following years. It is likely that three-year-time period is too short for expected effect to take place. Meanwhile, combination of contaminated ash and $\mathrm{KCl}$ had an effect already on the second year after fertilization; ${ }^{137} \mathrm{Cs} \mathrm{TF}$ reduction after fertilization was about $40 \%$ (table 1).

Oak. There was about 30 and $40 \%$ reduction of ${ }^{137} \mathrm{Cs}$ TF from forest soil to oak shoots in the second (2013) and the third (2014) year after fertilization with potassium fertilizer and with contaminated ash. Meanwhile, combined application of potassium fertilization and contaminated ash appeared to be the most effective in reducing of radionuclide transfer from forest soil to oak shoots: ${ }^{137} \mathrm{Cs}$ TF in the second and the third years after fertilization for this treatment were about 70\% lower compared to control plants (table 1). 
Uncontaminated wood ash either alone or in combination with potassium fertilizer had no effect on ${ }^{137} \mathrm{Cs} \mathrm{TF}$ from forest soil to oak shoots.

\section{CONCLUSIONS}

Single fertilization with potassium fertilizer reduced ${ }^{137} \mathrm{Cs} \mathrm{TF}$ already in the second and the third year for aboveground part of cowberry, young shoots and leaves of rowan and oak tree, however there was no or negative effect for blueberry plants as well as for shoots and leaves of birch and buckthorn. There was, however, a clear trend, showing that achievement of a positive effect for potassium fertilization is likely the matter of time. Combined application of potassium fertilization and uncontaminated ash appeared to be more effective: ${ }^{137} \mathrm{Cs}$ TF progressively decreased in following years after application for all studied species except oak. The overall effect of the combined application of potassium fertilization and uncontaminated ash on ${ }^{137} \mathrm{Cs}$ TF to investigated plants/trees in following after fertilization years is found to be positive and about $30 \%$ reduction of radiocesium uptake can be achieved. Application of contaminated wood ash is found to be more effective to reduce radiocesium uptake: obvious positive effect of contaminated wood ash application to forest soil was seen for all studied plants/trees. ${ }^{137} \mathrm{Cs} \mathrm{TF}$ from soil to plants/trees due to soil fertilization with contaminated wood ash in studied plants/trees decreased in following after fertilization years by about $36 \%$. Application of uncontaminated wood ash appeared to be less pronounced, however caused obvious reduction of ${ }^{137} \mathrm{Cs}$ $\mathrm{TF}$ in following years for aboveground part of blueberry and cowberry, as well as young shoots and leaves of rowan tree. Combined application of potassium fertilization and contaminated ash appeared to be the most effective in reducing radiocesium transfer from soil to forest plants. Reduction of ${ }^{137} \mathrm{Cs}$ uptake by forest plants/trees growing on fertilized plots in the second and the third (fourth) year after fertilization is found to be $55 \%$ lower than by control plants/trees. The highest effect of soil fertilization on radiocesium transfer reduction is achieved already on the second or the third/fourth year after fertilization.

Based on the obtained results it can be concluded that application of ${ }^{137} \mathrm{Cs}$-contaminated ashes in combination with potassium fertilizer $(50 / 50)$ in forest soil is a feasible countermeasure aiming to reduce cesium uptake by forest plants and trees.

\section{REFERENCES}

1. Reducing the Consumption of ${ }^{137} \mathrm{Cs}$ Via Forest Fungi-Provision of 'Self-Help' Advice / N. Beresford, B. Howard, C. Barnett et al. // Contaminated Forests. NATO Science Series. - 1999. - No. 58. - P. 359-368.

2. Kostiainen E. ${ }^{137} \mathrm{Cs}$ in Finnish wild berries mushrooms and game meat in 2000-2005/ E. Kostiainen // Boreal Environmental Research. - 2007. No. 12. - P. 23-28.

3. Nilsson T. Wood ash application - effects on elemental turnover in a cutover peatland and uptake in vegetation. Doctor's dissertation. Acta Universitatis Agriculturae Sueciae. - Silvestria, 2001. - 208 p.

4. Long-term effects of single potassium fertilization on ${ }^{137} \mathrm{Cs}$ levels in plants and fungi in a boreal forest ecosystem / K. Rosén, V. Vinichuk, I. Nikolova, K. Johanson // Journal of Environmental Radioactivity. - 2011. - No. 102. - P. 178-184.

5. Möre $H$. Strålskyddskonsekvenser vid villaldning med ${ }^{137} \mathrm{Cs}$-kontaminerad ved / H. Möre, L. Hubbard // Statens strålskyddsinsitut, SSI Rapport. 2002. -No. 6. - S. 21.
6. Levula T. Effects of ash fertilization and prescribed burning on macronutrient, heavy metal, sulphur and ${ }^{137} \mathrm{Cs}$ concentrations in lingonberries (Vacciniumvitis-idaea) / T. Levula, A. Saarsalmi, A. Rantavaara // Forest Ecology and Management. - 2000. No. 126. - P. 269-279.

7. Vetikko $V$. Uptake of ${ }^{137} \mathrm{Cs}$ by berries, mushrooms and needles of Scots pine in peatland forests after wood ash application / V. Vetikko, A. Rantavaara, M. Moilanen / Journal of Environmental Radioactivity. - 2010. - No. 101. - P. 1055-1060.

8. Högbom L. The fate of ${ }^{137} \mathrm{Cs}$ in conifeous forests following the application of wood-ash / L. Högbom, H. Nohrstedt // The Science of the Total Environment. -2001. - No. 280. - P. 133-141.

9. Strandberg $M .{ }^{134} \mathrm{Cs}$ in heather seed plants grown with and without mycorrhiza / M. Strandberg, M. Johansson // Journal of Environmental Radioactivity. - 1998. - No. 40. - P. 175-184.

10. Influence of fertilizing on the ${ }^{137} \mathrm{Cs}$ soil-plant transfer in a spruce forest of Southern Germany / G. Zibold, E. Klemt, I. Konopleva, A. Konoplev // Journal of 
Environmental Radioactivity. - 2009. - No. 100. - P. 489-496.

11. Aro L. Long-term effect of fertilization on ${ }^{137} \mathrm{Cs}$ concentration in Scots pine needles / L.Aro, A. Rantavaara //Radioprotection. - 2011.- No. 46 (6). - P. 479-482.

12. Weimer $R$. Temporal and Spatial Variation of Radiocaesium in Moose (Alcesalces) Following the Chernobyl Fallout in Sweden / R. Weimer Licentiate Thesis. Faculty of Natural Resources and Agricultural Sciences. Department of Aquatic Sci- ences and Assessment Uppsala. ISBN (print version) 978-91-576-9341-9.

13. Schley L. Diet of wild boar Sus scrofa in Western Europe, with particular reference to consumption of agricultural crops / L. Schley, T. Roper // Mammal Review. - 2003. -No. 33. - P. 43-56.

14. Handbook of Parameter Values for the Prediction of Radionuclide Transfer in Terrestrial and Freshwater Environments. - Vienna: Technical reports series, 2010. - 208 p.

\section{REFERENCES}

1. Beresford N., Howard B., Barnett C. Beresford N. (1999). Reducing the Consumption of ${ }^{137} \mathrm{Cs} \mathrm{Via}$ Forest Fungi-Provision of 'Self-Help' Advice Contaminated Forests. NATO Science Series, No. 58, pp. 359-368 (in English).

2. Kostiainen E. (2007). ${ }^{137} \mathrm{Cs}$ in Finnish wild berries mushrooms and game meat in 2000-2005. Boreal Environmental Research. No. 12, pp. 23-28 (in English).

3. Nilsson T. (2001). Wood ash application - effects on elemental turnover in a cutover peatland and uptake in vegetation. Doctor's dissertation. Acta Universitatis Agriculturae Sueciae, Silvestria 208 p. (in English).

4. Rosén K., Vinichuk V., Nikolova I, Johanson K. (2011). Long-term effects of single potassium fertilization on ${ }^{137} \mathrm{Cs}$ levels in plants and fungi in a boreal forest ecosystem, Journal of Environmental Radioactivity No. 102., pp. 178-184 (in English).

5. Möre H., Hubbard L. (2002). Strålskyddskonsekvenser vid villaldning med ${ }^{137} \mathrm{Cs}$-kontaminerad ved, Statens strålskyddsinsitut, SSI Rapport, No. 06, 21 sid. (in Swedish).

6. Levula T. Saarsalmi A., Rantavaara A. (2000). Effects of ash fertilization and prescribed burning on macronutrient, heavy metal, sulphur and ${ }^{137} \mathrm{Cs}$ concentrations in lingonberries (Vaccinium vitisidaea), Forest Ecology and Management, No. 126, pp. 269-279 (in English).

7. Vetikko V., Rantavaara A., Moilanen M. (2010). Uptake of ${ }^{137} \mathrm{Cs}$ by berries, mushrooms and needles of Scots pine in peatland forests after wood ash application, Journal of Environmental Radioactivity, No. 101, pp. 1055-1060 (in English).
8. Högbom L., Nohrstedt H. (2001). The fate of ${ }^{137} \mathrm{Cs}$ in conifeous forests following the application of wood-ash. The Science of the Total Environment, No. 280, pp. 133-141 (in English).

9. Strandberg M., Johansson M. (1998). ${ }^{134} \mathrm{Cs}$ in heather seed plants grown with and without mycorrhiza, Journal of Environmental Radioactivity, No. 40, pp. 175-184 (in English).

10. Zibold G., Klemt E., Konopleva I., Konoplev A. (2009). Influence of fertilizing on the ${ }^{137}$ Cs soilplant transfer in a spruce forest of Southern Germany, Journal of Environmental Radioactivity, No. 100, pp. 489-496 (in English).

11. Aro L., Rantavaara A. (2011). Long-term effect of fertilization on ${ }^{137} \mathrm{C}$ s concentration in Scots pine needles, Radioprotection, No. 46(6), pp. 479-482 (in English).

12. Weimer R. Temporal and Spatial Variation of Radiocaesium in Moose (Alces alces) Following the Chernobyl Fallout in Sweden, Licentiate Thesis. Faculty of Natural Resources and Agricultural Sciences. Department of Aquatic Sciences and Assessment Uppsala. ISBN (print version) 978-91-576-9341-9 (in English).

13. Schley L., Roper T. (2003). Diet of wild boar Sus scrofa in Western Europe, with particular reference to consumption of agricultural crops, Mammal Review, No. 33, pp. 43-56 (in English).

14. Handbook of Parameter Values for the Prediction of Radionuclide Transfer in Terrestrial and Freshwater Environments (2010). Technical reports series, Vienna, 208 p. (in English). 